\title{
Wintertime aerosol optical and radiative properties in the Kathmandu Valley during the SusKat-ABC field campaign
}

\author{
Chaeyoon Cho ${ }^{1}$, Sang-Woo Kim ${ }^{1}$, Maheswar Rupakheti ${ }^{2}$, Jin-Soo Park ${ }^{3}$, Arnico Panday ${ }^{4}$, Soon-Chang Yoon ${ }^{1}$, \\ Ji-Hyoung Kim ${ }^{1}$, Hyunjae Kim ${ }^{3}$, Haeun Jeon ${ }^{3}$, Minyoung Sung ${ }^{3}$, Bong Mann Kim ${ }^{5}$, Seungkyu K. Hong ${ }^{1,6}$, \\ Rokjin J. Park ${ }^{1}$, Dipesh Rupakheti ${ }^{7}$, Khadak Singh Mahata ${ }^{2}$, Puppala Siva Praveen ${ }^{4}$, Mark G. Lawrence ${ }^{2}$, and \\ Brent Holben ${ }^{8}$ \\ ${ }^{1}$ School of Earth and Environmental Science, Seoul National University, 08826 Seoul, South Korea \\ ${ }^{2}$ Institute for Advanced Sustainability Studies, Berliner Str. 130, 14467 Potsdam, Germany \\ ${ }^{3}$ National Institute of Environmental Research, 22689 Incheon, South Korea \\ ${ }^{4}$ International Centre for Integrated Mountain Development, 44700 Kathmandu, Nepal \\ $5 \mathrm{iGBu}$, Corona, CA 92882, USA \\ ${ }^{6}$ National Institute of Meteorological Sciences, 63568 Seogwipo, South Korea \\ ${ }^{7}$ Key Laboratory of Tibetan Environment Changes and Land Surface Processes, Institute of Tibetan Plateau Research, \\ Chinese Academy of Sciences, Beijing, 100101, China \\ ${ }^{8}$ NASA Goddard Space Flight Center, Greenbelt, MD 20771, USA
}

Correspondence to: Sang-Woo Kim (sangwookim@snu.ac.kr)

Received: 14 March 2017 - Discussion started: 9 May 2017

Revised: 14 September 2017 - Accepted: 20 September 2017 - Published: 24 October 2017

\begin{abstract}
Particulate air pollution in the Kathmandu Valley has reached severe levels that are mainly due to uncontrolled emissions and the location of the urban area in a bowl-shaped basin with associated local wind circulations. The AERONET measurements from December 2012 to August 2014 revealed a mean aerosol optical depth (AOD) of approximately 0.30 at $675 \mathrm{~nm}$ during winter, which is similar to that of the post-monsoon but half of that of the pre-monsoon AOD (0.63). The distinct seasonal variations are closely related to regional-scale monsoon circulations over South Asia and emissions in the Kathmandu Valley. During the SusKat-ABC campaign (December 2012February 2013), a noticeable increase in both aerosol scattering $\left(\sigma_{\mathrm{s}} ; 313 \rightarrow 577 \mathrm{Mm}^{-1}\right.$ at $\left.550 \mathrm{~nm}\right)$ and absorption $\left(\sigma_{\mathrm{a}}\right.$; $98 \rightarrow 145 \mathrm{Mm}^{-1}$ at $520 \mathrm{~nm}$ ) coefficients occurred before and after 4 January 2013. This can be attributed to the increase in wood-burned fires due to a temperature drop and the start of firing at nearby brick kilns. The $\sigma_{\mathrm{s}}$ value in the Kathmandu Valley was a factor of 0.5 lower than that in polluted cities in India. The $\sigma_{\mathrm{a}}$ value in the Kathmandu Valley was approximately 2 times higher than that at severely polluted urban sites in India. The aerosol mass scattering
\end{abstract}

efficiency of $2.6 \mathrm{~m}^{2} \mathrm{~g}^{-1}$ from $\mathrm{PM}_{10}$ measurements in the Kathmandu Valley is similar to that reported in urban areas. However, the aerosol mass absorption efficiency was determined to be $11 \mathrm{~m}^{2} \mathrm{~g}^{-1}$ from $\mathrm{PM}_{10}$ measurements, which is higher than that reported in the literature for pure soot particles $\left(7.5 \pm 1.2 \mathrm{~m}^{2} \mathrm{~g}^{-1}\right)$. This might be due to the fact that most of the carbonaceous aerosols in the Kathmandu Valley were thought to be mostly externally mixed with other aerosols under dry conditions due to a short travel time from their sources. The $\sigma_{\mathrm{s}}$ and $\sigma_{\mathrm{a}}$ values and the equivalent black carbon (EBC) mass concentration reached up to $757 \mathrm{Mm}^{-1}, 224 \mathrm{Mm}^{-1}$, and $29 \mu \mathrm{g} \mathrm{m}^{-3}$ at 08:00 LST (local standard time), respectively but decreased dramatically during the daytime (09:00-18:00 LST), to one-quarter of the morning average (06:00-09:00 LST) due to the development of valley winds and an atmospheric bounder layer. The $\sigma_{\mathrm{s}}$ and $\sigma_{\mathrm{a}}$ values and the EBC concentration remained almost constant during the night at the levels of $410 \mathrm{Mm}^{-1}, 130 \mathrm{Mm}^{-1}$, and $17 \mu \mathrm{g} \mathrm{m}^{-3}$, respectively. The average aerosol direct radiative forcings over the intensive measurement period were estimated to be $-6.9 \pm 1.4 \mathrm{~W} \mathrm{~m}^{-2}$ (top of the atmosphere) and $-20.8 \pm 4.6 \mathrm{~W} \mathrm{~m}^{-2}$ (surface). Therefore, the high at- 
mospheric forcing (i.e., $13.9 \pm 3.6 \mathrm{~W} \mathrm{~m}^{-2}$ ) and forcing efficiency $\left(74.8 \pm 24.2 \mathrm{~W} \mathrm{~m}^{-2} \tau^{-1}\right)$ can be attributed to the high portion of light-absorbing aerosols in the Kathmandu Valley, as indicated by the high black carbon (or elemental carbon) to sulphate ratio $(1.5 \pm 1.1)$.

\section{Introduction}

The Kathmandu Valley in Nepal has been experiencing increasingly serious air pollution over recent decades because of rapid population growth and urbanization and the associated growth of economic activities and fuel consumption (CBS, 2006). Particulate air pollution in the Kathmandu Valley has reached severe levels that is mainly due to uncontrolled emissions from motor vehicles (e.g., super-emitters such as diesel trucks), brick kilns, fugitive soil dust, and biomass and garbage burning (Panday and Prinn, 2009; Kim et al., 2015; Sarkar et al., 2016). Electrical power shortages in the Kathmandu Valley, especially during dry cold months, have led to not only increased low-grade coal and biomass/biofuel burnings but also the use of mostly small diesel generators between 2011 and 2016 (Chen et al., 2015). In addition, the Kathmandu Valley is located downwind of the Indo-Gangetic Plain region that experienced rapid growth in emissions and severe air quality degradation. All of this has resulted in elevated air pollution concentrations, especially during the dry season (Sapkota and Dhaubhadel, 2002; Shrestha and Shrestha, 2005; Sharma et al., 2012; Kiros et al., 2016). In addition, the bowl-shaped structure of the Kathmandu Valley, with a bottom altitude of $\sim 1.3 \mathrm{~km}$ and a rim of 2 to $2.8 \mathrm{~km}$, and topography-induced circulations have made the air pollution more serious by limiting the transport of air pollutants out of the valley (Regmi et al., 2003; Panday and Prinn, 2009).

Many studies reported various atmospheric compounds, mainly gases and aerosols, and associated temporal patterns with meteorological conditions in the Kathmandu Valley (Sapkota and Dhaubhadel, 2002; Shrestha and Shrestha, 2005; Stone et al., 2010; Chen et al., 2015; Kim et al., 2015; Kiros et al., 2016). Panday and Prinn (2009) described a very regular pattern of morning and evening peaks of the $\mathrm{CO}$ and $\mathrm{PM}_{10}$ concentrations occurring daily in the valley bottom, interspersed with low values in the afternoons and at night. Sharma et al. (2012) communicated that the black carbon (BC) concentration shows a significant temporal variation with a monthly mean concentration varying between 14.9 and $3.0 \mu \mathrm{g} \mathrm{m}^{-3}$. Chen et al. (2015) observed that the total suspended particles (TSPs) and polycyclic aromatic hydrocarbons in the TSP were relatively high in the Kathmandu Valley compared with those observed in other parts of Asia. Most previous studies performed in the Kathmandu Valley focused on adverse health effects and reduced visibility; however, limited measurement-based research was con- ducted to estimate the radiative effects of air pollutants (e.g., Ramana et al., 2004).

In this study, we analyzed the aerosol optical and chemical properties and their direct radiative effects in the Kathmandu Valley during the intensive phase of the Sustainable Atmosphere for the Kathmandu Valley - Atmospheric Brown Clouds (SusKat-ABC) campaign (December 2012February 2013; Rupakheti et al., 2017). In Sect. 3, we present seasonal variations in column-integrated and surface aerosol optical and radiative properties during the dry winter season. The diurnal cycle of aerosol properties and its relationship to local circulations in the valley is discussed in Sect. 4. Aerosol direct radiative effects estimated from columnar aerosol property measurements are given in Sect. 5. The conclusions drawn based on the findings are presented in Sect. 6 .

\section{Methods}

All ground-based in situ and column-integrated aerosol measurements were performed at the SusKat-ABC supersite in Bode $\left(27.68^{\circ} \mathrm{N}, 85.39^{\circ} \mathrm{E} ; 1360 \mathrm{~m}\right.$ a.m.s.l. - above mean sea level), which is located approximately $3 \mathrm{~km}$ east of the edge of Kathmandu city. Throughout the winter season, westerly winds generally transport polluted air masses from the urban area of Kathmandu to the observational site, from late morning until sunset (Regmi et al., 2003; Panday and Prinn, 2009).

The aerosol scattering coefficient $\left(\sigma_{\mathrm{s}}\right)$ was measured at three wavelengths $(450,550$, and $700 \mathrm{~nm})$ with a nephelometer (model 3563, TSI Inc.) from December 2012 to February 2013. The nephelometer-based scattering Ångström exponent (SÅE) was calculated from $\sigma_{\mathrm{s}}$ at 450 and $700 \mathrm{~nm}$. The nephelometer was calibrated using $\mathrm{CO}_{2}$ before, during, and after field deployment and all data were processed by applying the correction method described in Anderson and Ogren (1998). The aerosol absorption coefficient $\left(\sigma_{\mathrm{a}}\right)$ was measured with a 7 -wavelength aethalometer $(370,470,520$, 590, 660, 880, and $950 \mathrm{~nm}$; model AE31, Magee Scientific) over the campaign period. The aethalometer was run at a flow rate of $3.9 \mathrm{~L} \mathrm{~min}^{-1}$. However, the aethalometer data were analyzed only from 21 December 2012 to 9 January 2013, because the aethalometer data for the rest of the sampling period were not usable due to interference associated with an intermittent power supply at the observational site. The aethalometer data were corrected for filter-loading effects following the method suggested in Hansen et al. (1984) and Schmid et al. (2006).

Column-integrated spectral aerosol optical properties, such as the aerosol optical depth (hereafter, AOD or $\tau$ ), single scattering albedo $(\omega)$, and asymmetric parameter $(g)$, were obtained with the collocated 8-channel AERONET Cimel Sun/sky radiometer $(340,380,440,500,675,870,1020$, and $1640 \mathrm{~nm}$ ) from December 2012 to August 2014. The Ångström exponent $(\AA)$ was calculated using linear regres- 
sion of $\ln (\tau)$ vs. $\ln (\lambda)$ (i.e., wavelength) with the data obtained at $380,440,500,675$, and $870 \mathrm{~nm}$. These aerosol parameters were used in the column radiative model (CRM) as input data to calculate the aerosol direct radiative forcing and forcing efficiency (Won et al., 2004; Kim et al., 2010). The CRM uses a $\delta$-Eddington approximation with 19 spectral intervals spanning from 0.2 to $5 \mu \mathrm{m}$ and accounts for several gas absorption spectra; seven spectral bands of $\mathrm{O}_{3}$ and $\mathrm{H}_{2} \mathrm{O}$, three of $\mathrm{CO}_{2}$, and absorption bands of $\mathrm{N}_{2} \mathrm{O}, \mathrm{CH}_{4}, \mathrm{CFC}-11$, and CFC-12 are included (Slingo, 1989; Briegleb, 1992). In this study, a linear regression method in the $\log \lambda-\log \chi$ plane ( $\chi$ denotes $\tau, \omega$, and $g$ ) was used to determine the aerosol parameters in $19 \lambda$ bands and the number of computational vertical layers was extended from 18 to 54 based on Won et al. (2004).

Twenty-four-hour $\mathrm{PM}_{10}$ filter samples, each starting at 09:00 LST, were collected between December 2012 and February 2013 using two $\mathrm{PM}_{10}$ sequential samplers (model PMS-103, APM Engineering) with a sample flow rate of $16.7 \mathrm{~L} \mathrm{~min}^{-1}$, which were placed on the roof of a five-story building at the Bode supersite (Kim et al., 2015). The $\mathrm{PM}_{10}$ filter samples were analyzed for chemical composition, including organic carbon (OC), elemental carbon (EC), and ions, at the laboratory of the National Institute of Environmental Research (NIER), South Korea. The water-soluble ionic species were extracted from Zefluor ${ }^{\mathrm{TM}}$ supported PTFE filters and analyzed using ion chromatography (Dionex IC 2000) following the USEPA IO-4.1 method. The $\mathrm{PM}_{10}$ samples collected on quartz fiber filters (pretreated at $850^{\circ} \mathrm{C}$ for $4 \mathrm{~h}$ before sampling) were analyzed for EC and OC using a thermal optical transmittance carbon analyzer (Lab OC-EC aerosol analyzer model 5, Sunset Laboratory Inc.) following the USEPA NIOSH 5040 protocol (Kim et al., 2015).

\section{Aerosol optical and radiative properties}

\subsection{Seasonal and monthly variation in columnar aerosol optical properties}

Figure 1 shows the seasonal and monthly variations in AOD, $\AA$, and $\omega$ and the aerosol volume size distribution from AERONET Cimel sun/sky radiometer measurements at the Bode site during December 2012-August 2014. Here, we note that the climate seasons in Nepal are divided into winter (December-February), pre-monsoon (March-May), summer monsoon (June-September), and post-monsoon (October-November) seasons (Sharma et al., 2012). The AOD $(675 \mathrm{~nm})$ maxima were observed in the pre-monsoon season $(0.63 \pm 0.12)$. The AOD was approximately 0.30 in the summer monsoon, post-monsoon, and winter seasons. As many studies reported, these temporal variations are closely related to distinct seasonal monsoon circulations over South Asia including the Himalayan foothills (Sapkota et al., 2002;

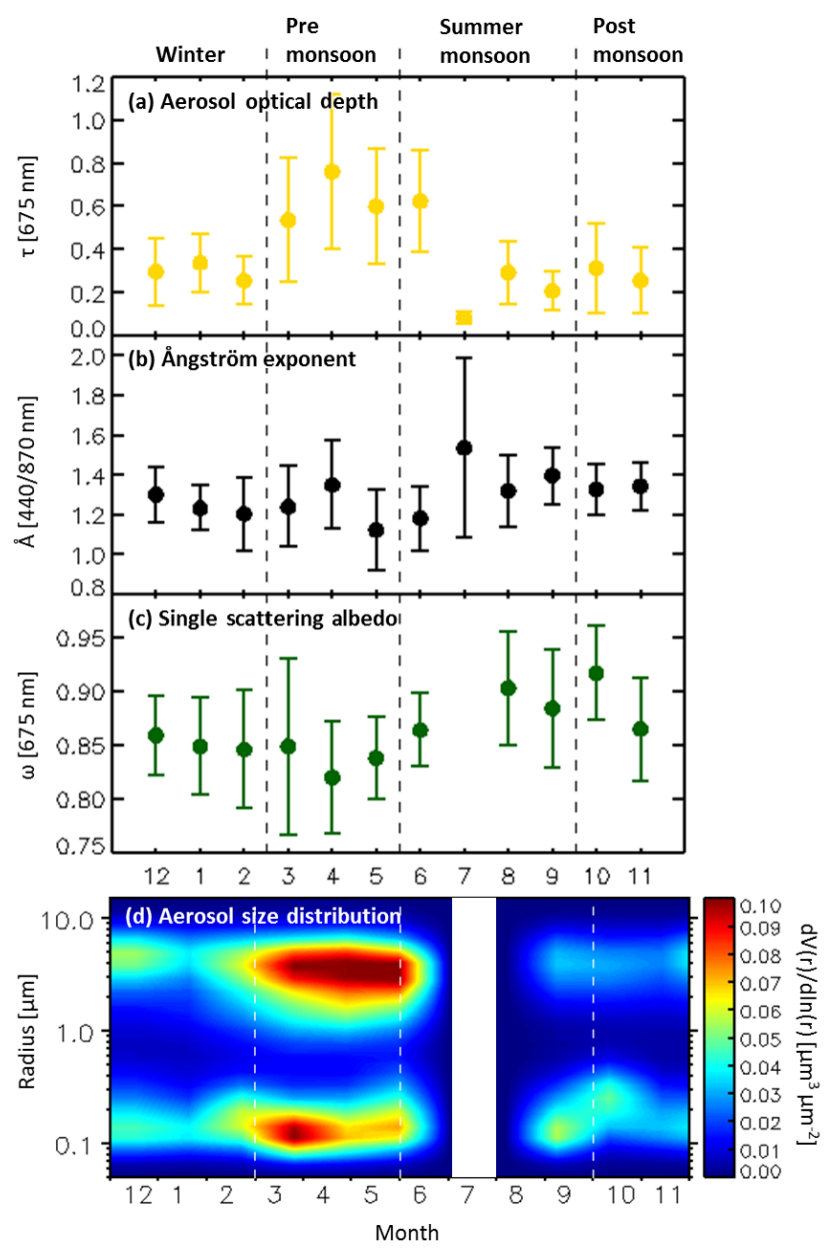

Figure 1. Monthly variation in (a) aerosol optical depth, (b) Ångström exponent, (c) single scattering albedo, and (d) aerosol volume size distribution from 1.75-year AERONET sun/sky radiometer measurements (December 2012 to August 2014) at Bode, Kathmandu Valley. The four seasons based on Sharma et al. (2012) are noted on top of the figure.

Sharma et al., 2012). Heavy precipitation in summer months (June-September) due to warm and marine air masses advected from the Indian Ocean by southerly flows (Carrico et al., 2003) efficiently removes atmospheric aerosols through the wet scavenging process (Sharma et al., 2012). After the end of the summer monsoon, on the other hand, atmospheric aerosol loadings gradually increase under the dry and stable atmospheric conditions in the Himalayan foothills and local emissions also increase (e.g., increase in the biomass burning in houses in cold months and use of low-grade coal and biomass in brick factories and kilns, which are operational from mid-December to mid-April). The peaks of AOD occurring in the pre-monsoon season can be explained by the combined effects of locally emitted pollution, wind-blown mineral dust particles, and regional forest and farm fires in the region. 


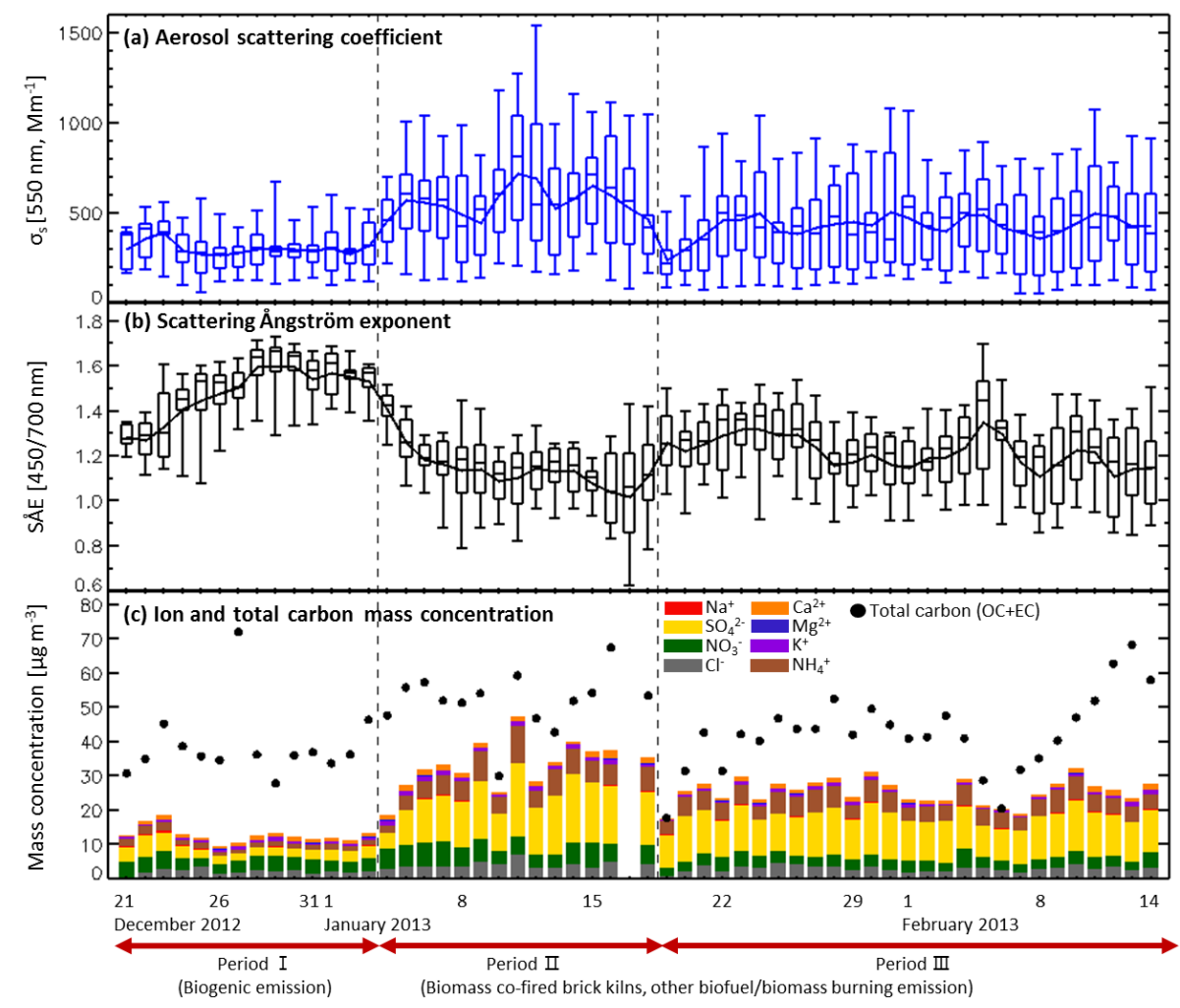

Figure 2. Daily variation in (a) aerosol scattering coefficient, (b) scattering Ångström exponent, and (c) chemical composition of PM 10 at the Bode supersite during the SusKat-ABC campaign. Based on Sarkar et al. (2016), the main source is biogenic emission in Period I (21 December 2012 to 3 January 2013) and biomass co-fired brick kilns and other biofuel/biomass burning emissions in Period II (418 January 2013). Period III is from 19 January to 14 February 2013.

The monthly mean A ranged between 1.1 and 1.6 during December 2012 and August 2014 (Fig. 1b), which implies that fine-mode particles are predominant all year round; however, coarse soil dust particles, mainly emitted from unpaved roads and farmland in the Kathmandu Valley, also exist, especially during dry winter and pre-monsoon periods. For example, about $26 \%$ of the average $\mathrm{PM}_{10}$ concentration in winter was attributed to soil dust during the SusKat-ABC campaign (Kim et al., 2015). This is more clearly evident in the aerosol volume size distribution (Fig. 1d). The comparison of the March-May period with other months showed an increase in coarse-mode particles with a modal radius of 3 to $6 \mu \mathrm{m}$ due to the presence of soil dust particles, as mentioned above. Enhanced fine-mode aerosols with a modal radius of $0.1-0.3 \mu \mathrm{m}$ in the pre-monsoon period can be explained by more emissions of accumulation-mode particles from brick kilns (Sarkar et al., 2016), motor vehicles, diesel generator sets, and forest fires and the frequent occurrence of new particle formation and subsequent growth events (Venzac et al., 2008). The aerosol volume size distribution in the monsoon and post-monsoon periods indicated a minimal content of coarse particles.

The average $\omega$ at $675 \mathrm{~nm}$ in the Kathmandu Valley during winter and pre-monsoon was $0.84 \pm 0.01$ (Fig. 1c), which is slightly lower than that at other locations in Asia (Xu et al., 2004; Kim et al., 2005). The low $\omega$ is likely due to a higher ratio of light-absorbing carbonaceous aerosols (i.e., black carbon) to total aerosol concentrations (Putero et al., 2015; Kim et al., 2015). This low value of $\omega$ was also observed in ground-based in situ measurements (Sect. 3.2), which results in high atmospheric radiative forcings (Sect. 5).

\subsection{Surface aerosol optical and chemical properties during the SusKat-ABC campaign}

Figure 2 shows the variations in the daily mean $\sigma_{\mathrm{s}}$, SÅE, ions, and total carbon (TC: sum of OC and EC) mass concentration in $\mathrm{PM}_{10}$ from surface-based measurements at the Bode supersite during the SusKat-ABC campaign. The $\sigma_{\mathrm{s}}$ and $\mathrm{SÅE}$ values averaged for the entire measurement period were estimated to be $432 \pm 266 \mathrm{Mm}^{-1}$ and $1.3 \pm 0.2$, respectively; however, the changes were significant as of $3-$ 4 and 18-19 January 2013, respectively. To explain the variability of these properties during the experiment, we divided our dataset into three periods: Period I (21 December 2012 to 3 January 2013), Period II (4-18 January 2013), and Period III (19 January to 14 February 2013). The $\sigma_{\mathrm{s}}$ value averaged over Period I was $313 \pm 135 \mathrm{Mm}^{-1}$ but distinctly in- 
creased in Period II $\left(577 \pm 310 \mathrm{Mm}^{-1}\right.$; Fig. 2a). The main source was biogenic emission in Period I based on Sarkar et al. (2016). In Periods II and III, they observed high acetonitrile, benzene, and isocyanic acid due to emissions from biomass co-fired brick kilns and other biofuel/biomass burning activities (see the bottom of Fig. 2). We determined much higher scattering coefficients during dust and pollution events in Asia than previous studies (Kim et al., 2005; see Fig. 4 for further comparison). The $\sigma_{\mathrm{s}}$ value during Period III resumed similar levels as in Period I, with an arithmetic mean remaining at $426 \pm 262 \mathrm{Mm}^{-1}$. The $\mathrm{SÅE}$ value during Period I ranged from approximately 1.3 to 1.6 but suddenly decreased to below 1.2 in Period II (Fig. 2b). We cannot explain why we observed the lowest value of SÅ (mean: $1.1 \pm 0.2$ ) in Period II because most of the fine scattering aerosols, such as $\mathrm{SO}_{4}^{2-}$ and $\mathrm{NH}_{4}^{+}$, increased sharply from 4 January 2013. The $\mathrm{Ca}^{2+}$ concentration, which is an indicator of soil dust, did not increase much in Period II. The higher concentrations of $\mathrm{SO}_{4}^{2-}$ and $\mathrm{NH}_{4}^{+}$in Period II were mainly due to increased emissions from brick kilns. The operation of brick kilns in 2013 started in the first week of January; almost all brick kilns in the Kathmandu Valley started to operate by 20 January 2013. This contributed to the increase in these ions and that of $\sigma_{\mathrm{s}}$. This means that the brick kiln activities in the valley are one of the predominant factors affecting the aerosol concentrations and aerosol optical properties in both Periods II and III compared with Period I. This can also be explained by a slight increase in the TC concentration in Periods II and III.

The cations and anions $\left(24 \pm 8 \mu \mathrm{g} \mathrm{m}^{-3}\right)$ accounted for approximately $17 \%$ of the average total $\mathrm{PM}_{10}$ mass concentration $\left(153 \pm 36 \mu^{-3} \mathrm{~m}^{-3}\right)$ during the entire measurement period. Table 1 shows the comparison of the ion mass concentration observed at polluted urban environments in Nepal, India, and China. Although the ion concentrations were measured for different sampling sizes, the ion concentrations in $\mathrm{PM}_{10}$ measured at the Kathmandu Valley were much lower than those in polluted urban cities in India (Hisar, Kanpur, and Allahabad) and China (Beijing). In contrast to the low ion concentrations, we found high TC concentrations in the $\mathrm{PM}_{10}$ filter samples. The $\mathrm{BC}$ (EC) to sulphate ratio for Periods I-III was $\sim 2.9 \pm 1.4,1.1 \pm 0.5$, and $1.0 \pm 0.3$, respectively, which is much higher than the values reported in East and South Asia (Ramana et al., 2010). This is consistent with the low $\omega$ and high atmospheric forcing that we report in Sects. 4 and 5.

Figure 3 shows the temporal variations in the aerosol properties and meteorological parameters from 21 December 2012 to 9 January 2013. Similar diurnal variations in $\sigma_{\mathrm{s}}, \sigma_{\mathrm{a}}$, EBC mass concentration, and meteorological parameters were observed during that period (see Sect. 4 for detailed discussion). As seen earlier in Fig. 2, Period II (4-9 January 2013) includes values of both $\sigma_{\mathrm{s}}$ $\left(577 \pm 310 \mathrm{Mm}^{-1}\right.$ at $\left.550 \mathrm{~nm}\right)$ and $\sigma_{\mathrm{a}}\left(145 \pm 82 \mathrm{Mm}^{-1}\right.$ at $520 \mathrm{~nm}$ ) that are $\sim 1.5$ times higher than that in Period I

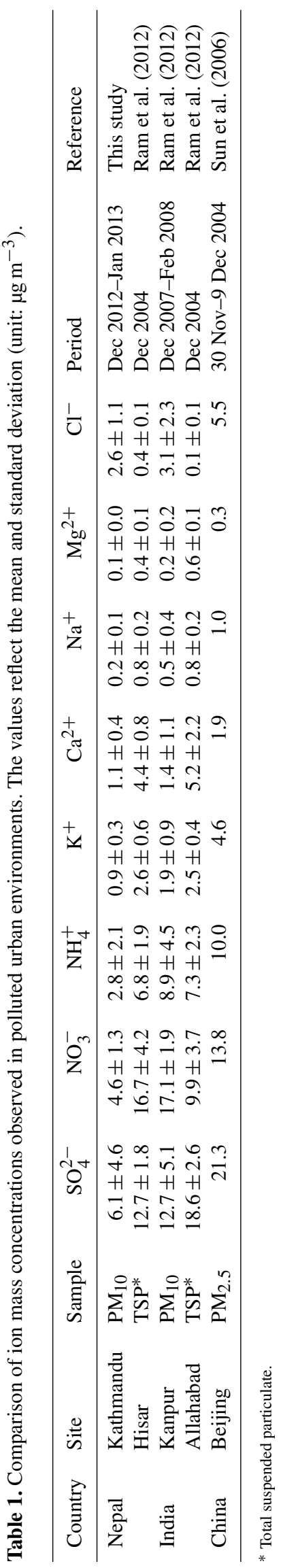

Atmos. Chem. Phys., 17, 12617-12632, 2017 

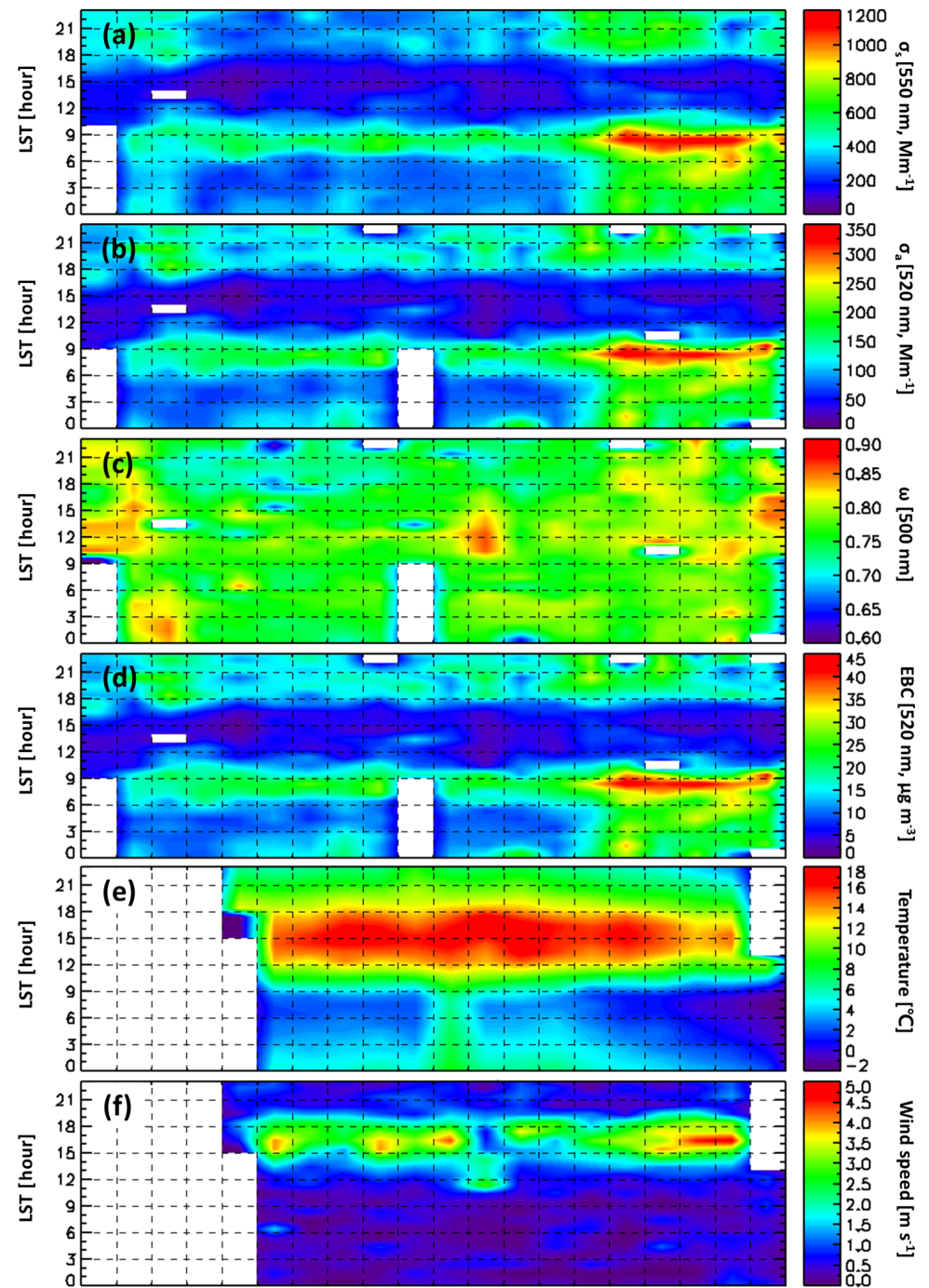

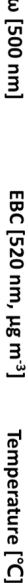

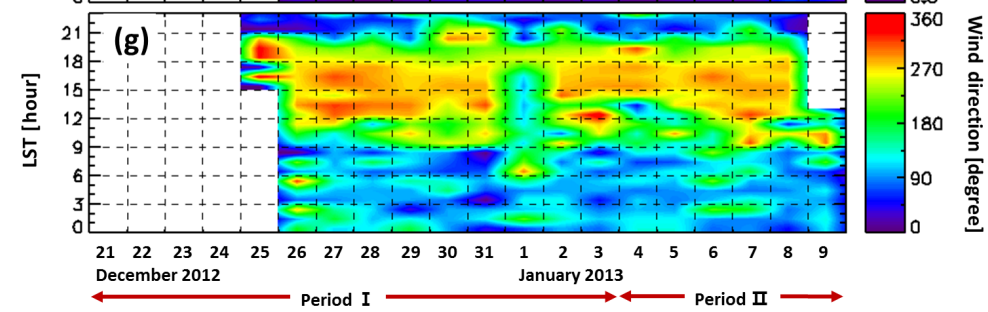

Figure 3. Hourly variation in the (a) aerosol scattering coefficient, (b) aerosol absorption coefficient, (c) single scattering albedo, (d) EBC mass concentration, (e) ambient temperature, (f) wind speed, and (g) wind direction at the Bode site in the Kathmandu Valley over the study period of 21 December 2012-9 January 2013.

(21 December 2012-3 January 2013; $\sigma_{\mathrm{s}}: 313 \pm 135 \mathrm{Mm}^{-1}$, $\left.\sigma_{\mathrm{a}}: 98 \pm 146 \mathrm{Mm}^{-1}\right)$. The EBC mass concentration also increased from $12 \pm 6 \mu \mathrm{g} \mathrm{m}^{-3}$ in Period I to $19 \pm 10 \mu \mathrm{g} \mathrm{m}^{-3}$ for the period of 4-9 January 2013. However, $\omega$ did not show any visible change before and after 4 January 2013 . The winds did not change much during the entire sampling period; however, the surface temperature decreased slightly after 4 January 2013 (i.e., Period II), which led to the increased usage of wood-burned fires indoors or outdoors. Additionally, as mentioned above, the emissions from biomass co-fired brick kilns increased in Period II after 4 January 2013 (Sarkar et al., 2016). Previous studies reported that the concentrations of $\mathrm{PM}_{10}$, particulate carbon, $\mathrm{SO}_{2}, \mathrm{NO}_{x}$, and volatile organic compounds increased considerably when nearby brick kilns were operating (Raut, 2003; Pariyar et al., 2013; Kiros et al., 2016; Sarkar et al., 2016, 2017). 


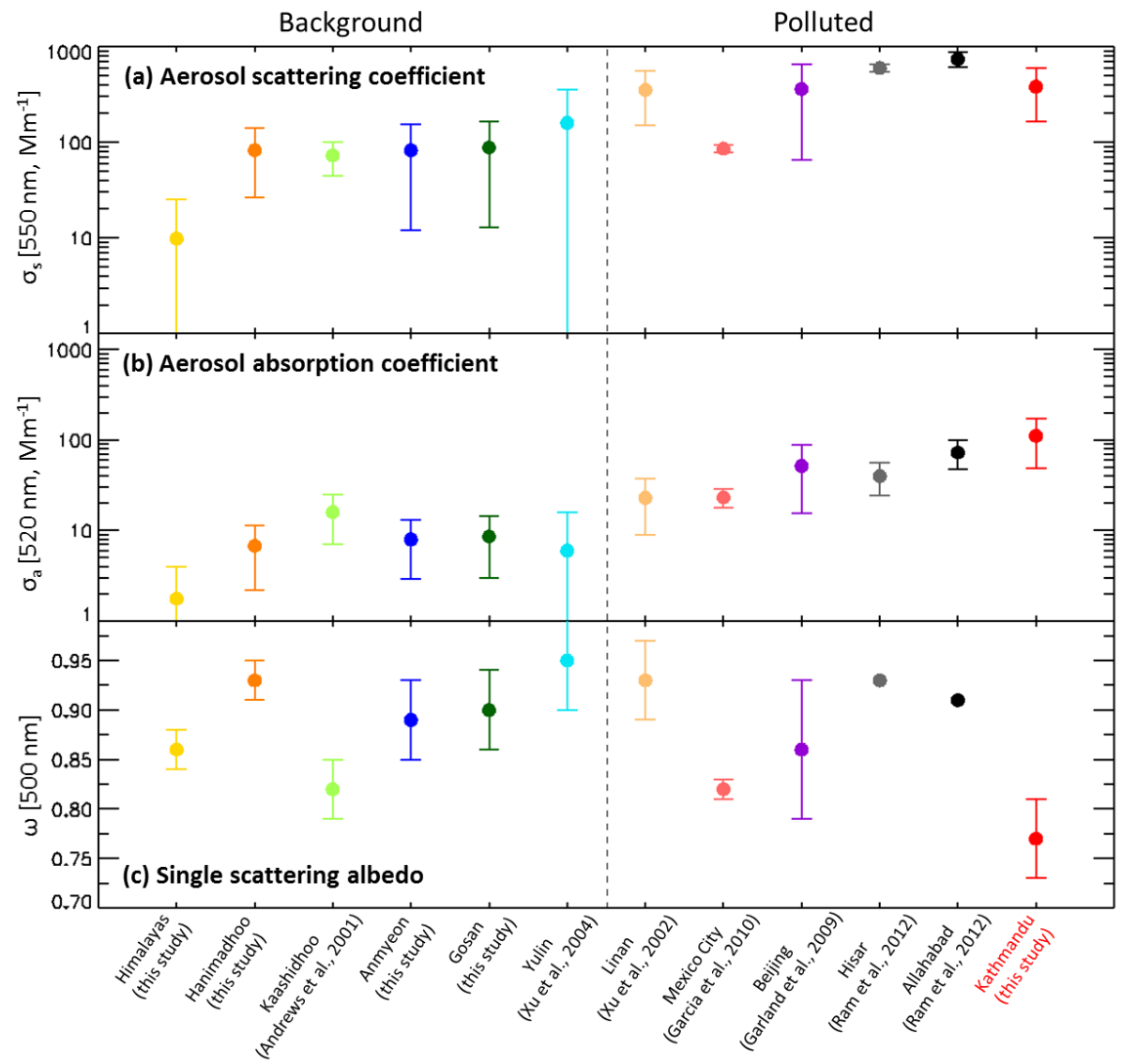

Figure 4. Comparison of the (a) aerosol scattering coefficient, (b) aerosol absorption coefficient, and (c) single scattering albedo measured at several locations worldwide, segregated by the background and polluted area. Note that the scale of the scattering and absorption coefficients is logarithmic $(\log )$.

The comparison of the aerosol properties observed in the Kathmandu Valley with those reported in previous studies in East and South Asia is given in Fig. 4. The $\sigma_{\mathrm{s}}$ value in the Kathmandu Valley is a factor of $0.5-0.6$ lower in polluted urban cities (Hisar and Allahabad) in India, while it is similar to that of Beijing (polluted urban) and Linan (rural but affected by a large city) in China. Compared with the values measured at background sites in Asia (Himalayas, Hanimadhoo, Kaashidhoo, Anmyeon, Gosan, and Yulin) and at an urban site in Mexico City, the $\sigma_{\mathrm{s}}$ value in Kathmandu Valley is about 4-5 times higher.

The $\sigma_{\mathrm{a}}$ value in the Kathmandu Valley was far higher than in any of the other studies listed in Fig. 4 throughout the measurement period. The $\sigma_{\mathrm{a}}$ value in the Kathmandu Valley was more than 100 times higher than that at the highaltitude site in the Himalaya (Nepal Climate Observatory Pyramid, $5079 \mathrm{~m}$ a.m.s.l.), roughly a factor of 12 higher than that at other background sites, and more than 2 times higher than that at severely polluted urban sites in India. The observed high $\sigma_{\mathrm{a}}$ is consistent with the large portion of lightabsorbing aerosols (i.e., black carbon or EC), as represented by the low $\omega$ with a range of $0.6-0.85$ at $520 \mathrm{~nm}$ (Sect. 3.1).

\subsection{Aerosol mass scattering and absorption efficiencies}

Table 2 shows the aerosol mass scattering efficiency $\left(Q_{\mathrm{s}}\right.$, $\left.\mathrm{m}^{2} \mathrm{~g}^{-1}\right)$ and aerosol mass absorption efficiency $\left(Q_{\mathrm{a}}, \mathrm{m}^{2} \mathrm{~g}^{-1}\right)$ estimated from the simultaneous measurements of aerosol optical and chemical properties. The $Q_{\mathrm{s}}$, calculated as the ratio of the averaged $\sigma_{\mathrm{s}}$ at $550 \mathrm{~nm}$ to the $\mathrm{PM}_{10}$ mass concentration over the period of 4-9 January 2013 (Period II), was a factor of 1.3 higher than that in Period I. The enhanced formation of secondary scattering aerosols from increased emissions of aerosol precursors (e.g., $\mathrm{SO}_{2}$ ), mainly from brick factories, as evident in the abundance of $\mathrm{SO}_{4}^{2-}, \mathrm{NO}_{3}^{-}$, and $\mathrm{NH}_{4}^{+}$concentrations in this period, is thought to be a possible factor for a higher $Q_{\mathrm{s}}$ value in Period II, in addition to direct emissions from brick kilns, motor vehicles, and house heating. Similar estimates of $Q_{\mathrm{s}}\left(2.2-4.4 \mathrm{~m}^{2} \mathrm{~g}^{-1}\right)$ have been found in other studies for both urban and rural areas (Bergin et al., 2001; Xu et al., 2002; Kim et al., 2005).

The $Q_{\mathrm{a}}$ value was calculated as the ratio of the averaged $\sigma_{\mathrm{a}}$ at $520 \mathrm{~nm}$ to the EC mass concentration from $\mathrm{PM}_{10}$ measurements. It was $\sim 11 \mathrm{~m}^{2} \mathrm{~g}^{-1}$ over the entire measurement period. This value is within the range of val- 
Table 2. Aerosol mass scattering efficiency (at $550 \mathrm{~nm}$ ) and aerosol mass absorption efficiency (at $520 \mathrm{~nm}$ ) for each period and all periods combined from 21 December 2012 to 9 January 2013 (unit: $\mathrm{m}^{2} \mathrm{~g}^{-1}$ ).

\begin{tabular}{lrrr}
\hline & $\begin{array}{r}\text { Period I } \\
\text { (21 December 2012- } \\
\text { 3 January 2013) }\end{array}$ & $\begin{array}{c}\text { Period II } \\
\text { (4-9 January 2013) }\end{array}$ & $\begin{array}{r}\text { All periods } \\
\text { (21 December 2012- } \\
\text { 9 January 2013) }\end{array}$ \\
\hline Aerosol scattering efficiency $\left(Q_{\mathrm{S}}\right)$ & $2.4 \pm 0.4$ & $3.2 \pm 1.2$ & $2.6 \pm 0.8$ \\
Aerosol absorption efficiency $\left(Q_{\mathrm{a}}\right)$ & $11.9 \pm 3.7$ & $9.6 \pm 0.6$ & $11.2 \pm 0.8$ \\
\hline
\end{tabular}

ues reported for polluted regions of $5-25 \mathrm{~m}^{2} \mathrm{~g}^{-1}$ in previous studies (Liousse et al., 1993; Xu et al., 2002; Kim et al., 2005; Schwarz et al., 2008). As reported by Bond and Bergstrom (2006), the $Q_{\mathrm{a}}$ value for pure soot particles at $550 \mathrm{~nm}$ is $7.5 \pm 1.2 \mathrm{~m}^{2} \mathrm{~g}^{-1}$; however, $Q_{\mathrm{a}}$ could double because the particles are mixed with other aerosol constituents (Jacobson, 2012). We can conclude that most of the carbonaceous aerosols in Bode were externally mixed with other aerosols under dry conditions during the transport over short distances (less than a few kilometers) from their sources, as discussed in Kim et al. (2015).

\section{Diurnal variations in aerosol and meteorological properties}

Figure 5 shows the diurnal cycles of aerosol and meteorological parameters, averaged over the study period. A distinct diurnal variation in the $\sigma_{\mathrm{s}}$ and $\sigma_{\mathrm{a}}$ values and the EBC mass concentration was observed, with two peaks occurring at 08:00 and 19:00 LST. On the other hand, the wind speed, temperature, and mixing layer height showed a peak around 15:00-16:00 LST. As already mentioned above, $\omega$ did not show much visible change during the day. This suggests that the proportion of light-absorbing aerosols of the total aerosol composition remained unchanged, likely because these were emitted from the same sources in the valley.

The distinct diurnal variations in aerosol optical properties were closely linked with unique local circulations in the Kathmandu basin, as explained in several previous studies (e.g., Panday and Prinn, 2009; Regmi et al., 2003). Figure 6 illustrates 3-hour averaged near-surface winds simulated by the Weather Research and Forecast (WRF) model over the Kathmandu Valley and Fig. 7 shows the coupling of winds and aerosol scattering and absorption coefficients for three time periods in a day, separated by color into morning (06:00-09:00 LST), daytime (09:00-18:00 LST), and night (18:00-06:00 LST). A detailed discussion of diurnal variations of aerosol optical and meteorological properties is provided below.

\subsection{6:00-09:00 LST (morning)}

The meteorological conditions at the valley basin in the morning were almost stagnant flows with calm winds (nearsurface wind speed $\leq 1 \mathrm{~m} \mathrm{~s}^{-1}$ ). The weakening of the downslope winds as the cold pool of air kept building through the night was also conducive to the accumulation of aerosols emitted within the valley basin throughout the night and early morning. The $\sigma_{\mathrm{s}}$ and $\sigma_{\mathrm{a}}$ values and EBC mass concentration at $520 \mathrm{~nm}$ were rapidly elevated from the values of $488 \mathrm{Mm}^{-1}, 146 \mathrm{Mm}^{-1}$, and $19 \mu \mathrm{g} \mathrm{m}^{-3}$ at 06:00 LST to the maximum values of $757 \mathrm{Mm}^{-1}, 224 \mathrm{Mm}^{-1}$, and $29 \mu \mathrm{g} \mathrm{m}^{-3}$ at 08:00 LST, respectively, because considerable amounts of aerosols, emitted from increased vehicles during the traffic rush hour and cooking activities, were added to pre-existing aerosols of the shallow nighttime boundary layer (Mues et al., 2017). The average value of $\sigma_{\mathrm{s}}$ and $\sigma_{\mathrm{a}}$ during the three hours was $628 \pm 252$ and $194 \pm 68 \mathrm{Mm}^{-1}$, respectively. The $\mathrm{SÅE}$ value, which increased from 1.4 at 06:00 LST to 1.8 at 08:00 LST (not shown), suggests that tiny particles were largely emitted from automobile and biofuel/biomass burning in the morning hours.

\subsection{9:00-18:00 LST (daytime)}

The development of the mixing layer height (MLH) and valley winds induced by solar heating in the high-altitude Kathmandu Valley played a crucial role in the reduction of the aerosol concentration near the surface by enhancing the vertical and horizontal ventilation (Panday and Prinn, 2009). The MLH estimated from ceilometer measurements varied from about $100 \mathrm{~m}$ in the nighttime to more than $1500 \mathrm{~m}$ above the ground during the day, reaching about $1000 \mathrm{~m}$ at 15:00 LST (Fig. 5; Panday and Prinn, 2009; Mues et al., 2017). Within the developed MLH, aerosols were both vertically mixed and ventilated out of the Kathmandu Valley by winds sweeping through. The up-valley winds entering along the Bagmati River gorge from the south and westerly winds passing through the Mudku, Bhimdhunga, and Nagdhunga passes merged into strong westerly winds in the Kathmandu Valley. The aerosols were carried by the westerly winds to the low mountain outflow passes at Sanga and Nala (Regmi et al., 2003). The westerly winds recorded speeds up to $5 \mathrm{~m} \mathrm{~s}^{-1}$ during the daytime, efficiently diluted polluted air masses within the valley basin 

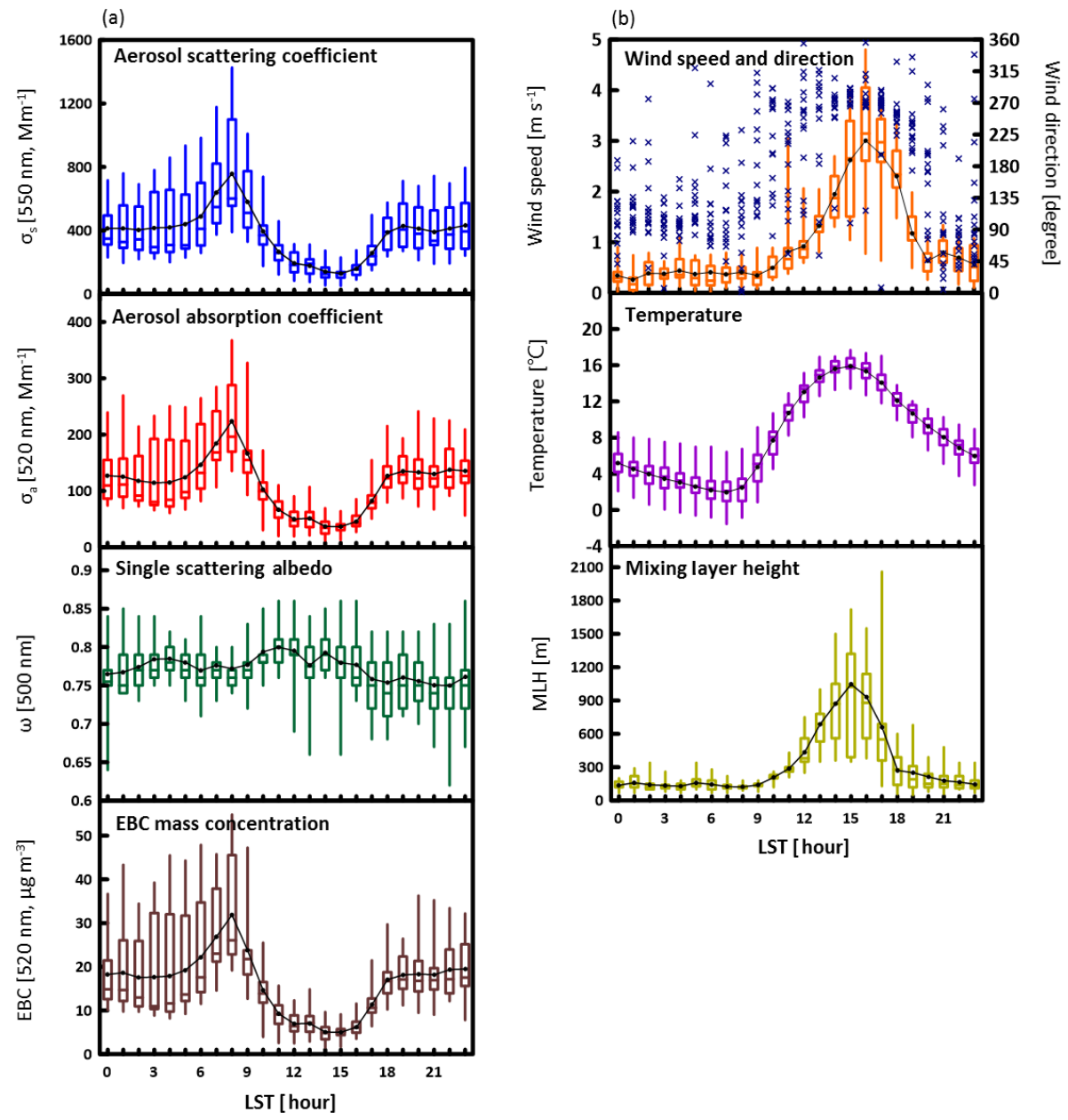

Figure 5. Diurnal cycle of the (a) aerosol optical properties and EBC mass concentration (blue box-whisker; scattering coefficient, red box-whisker; absorption coefficient, green box-whisker; single scattering albedo, brown box-whisker; EBC mass concentration; black lines are mean values) and (b) meteorological parameters (orange box-whisker; wind speed, $x$ symbol; wind direction, purple box-whisker; temperature, yellow box-whisker; mixing layer height; black lines are mean values) at Bode in the Kathmandu Valley. Note that the mixing layer height was measured by a ceilometer from 27 January 2013-14 February 2013 (see Mues et al., 2017 for more information on ceilometer measurements at Bode).

and led to decreased $\sigma_{\mathrm{s}}\left(250 \pm 164 \mathrm{Mm}^{-1}\right.$ at $\left.550 \mathrm{~nm}\right)$ and $\sigma_{\mathrm{a}}\left(70 \pm 50 \mathrm{Mm}^{-1}\right.$ at $520 \mathrm{~nm}$; Fig. 7) values. The $\sigma_{\mathrm{s}}$ value at $550 \mathrm{~nm}, \sigma_{\mathrm{a}}$ at $520 \mathrm{~nm}$, and the EBC mass concentration at $520 \mathrm{~nm}$ decreased to minimum values of $130 \mathrm{Mm}^{-1}$, $37 \mathrm{Mm}^{-1}$, and $5 \mu \mathrm{g} \mathrm{m}^{-3}$ at 15:00 LST, respectively (Fig. 5). On the other hand, it should be noted that AOD at $500 \mathrm{~nm}$ observed in the afternoon (14:00-18:00 LST) was about 1.52 times higher than that observed before 14:00 LST. For example, AOD at $500 \mathrm{~nm}$ was distinctly increased from about 0.3 around $09: 00-14: 00$ LST to 0.5 in the late afternoon (15:00-17:00 LST) on 3 January 2013 (Fig. 8). An AOD increase in the afternoon (14:00-18:00 LST) can be attributable to enhanced vertical mixing within the developed MLH.

\section{$4.3 \quad 18: 00-06: 00$ LST (nighttime)}

When the inflows from southern and western passes retreated (wind speed $\leq 3 \mathrm{~m} \mathrm{~s}^{-1}$ ) after the sunset, second peaks of the $\sigma_{\mathrm{s}}$ and $\sigma_{\mathrm{a}}$ values and EBC mass concentration appeared at approximately 19:00 LST. These high values remained stable throughout the night. In addition to the abrupt collapse of the boundary layer height, the aerosol concentrations of the night were mostly contributed by emissions from vehicles, cooking activities, and house heating in the early evening. The use of diesel-fired power generators might also contribute to the elevated $\sigma_{\mathrm{s}}, \sigma_{\mathrm{a}}$, and EBC mass concentration. Based on Chen et al. (2015), Nepal experienced acute power shortages, particularly during winter (e.g., $10-18 \mathrm{~h}$ power cuts in a day), which resulted in the use of nearly 250000 small diesel generators. Because of the emission of these aerosols, 


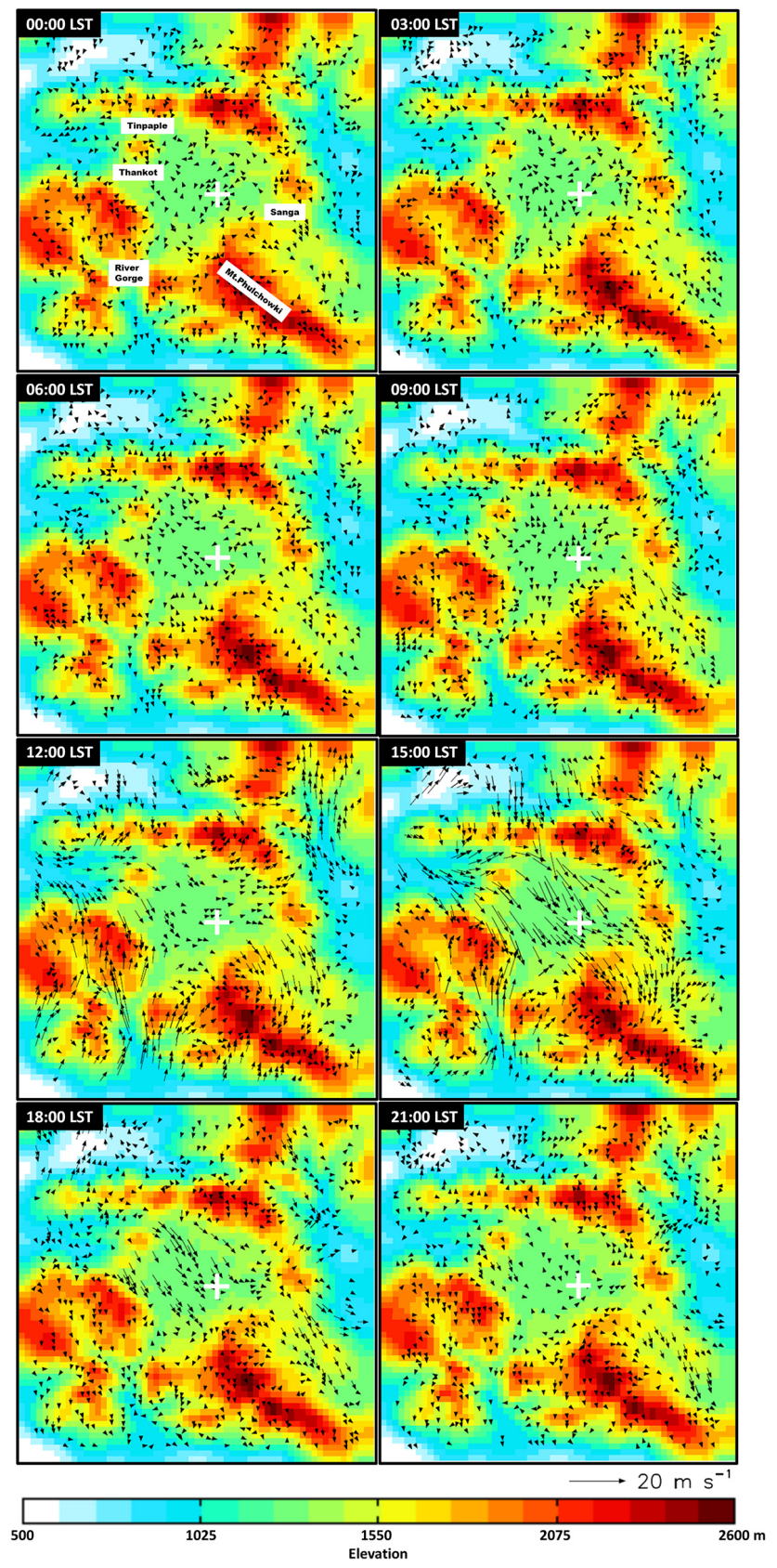

Figure 6. WRF simulation of near-surface winds for every three hours averaged during the study period in Kathmandu. The white crosshair is the location of the Bode site; the color shade represents the elevation $(\mathrm{m})$.

the residual aerosols during the daytime were also trapped in the collapsed boundary layer due to the radiative cooling at the surface. Earlier studies found evidence of nighttime lifting of pollutants over the valley as a result of converging katabatic winds. In the early morning, the elevated pollutants returned to the surface when the mixing layer grew and entrained the lifted layer, as explained before by Panday and Prinn (2009), adding to the growing morning emis- sions that caused the morning peak described above. The average value of $\sigma_{\mathrm{s}}$ and $\sigma_{\mathrm{a}}$ during the night was estimated to be $410 \pm 163 \mathrm{Mm}^{-1}$ at $550 \mathrm{~nm}$ and $130 \pm 47 \mathrm{Mm}^{-1}$ at $520 \mathrm{~nm}$, respectively, which is a factor of 0.6 lower than the value of the maximum peak in the morning.

\section{Aerosol radiative forcing effects}

Figure 9 shows the daily mean AOD, $\omega$, and aerosol direct radiative forcing $(\triangle \mathrm{DRF})$ estimated from the AERONET sun/sky radiometer measurements at the Bode supersite from 21 December to 9 January 2013. The daily mean AOD at $675 \mathrm{~nm}$ ranged from 0.2 to 0.4 , with an average AOD of $0.29 \pm 0.07$. Contrary to in situ surface aerosol measurements, which showed a significant change in the aerosol properties between periods I and II (Sects. 3 and 4), AOD did not show such a big change between the two periods. This discrepancy can be attributed to the fact that the sun/sky radiometer measurements were made only for the daytime under cloud-free conditions when aerosols were naturally diluted due to the development of a mixing layer and local circulations. Similar to AOD, the aerosol extinction coefficient $\left(\sigma_{\mathrm{e}}\right)$ at $500 \mathrm{~nm}$ at the surface during the daytime (09:0018:00 LST) was $37 \%$ lower in Period I $\left(285 \mathrm{Mm}^{-1}\right)$ than in Period II $\left(392 \mathrm{Mm}^{-1}\right)$. In the nighttime, $\sigma_{\mathrm{e}}$ was about $75 \%$ lower in Period I $\left(468 \mathrm{Mm}^{-1}\right)$ than in Period II $\left(817 \mathrm{Mm}^{-1}\right)$. This means that the increase in the surface aerosols due to increased emissions in Period II was more concentrated under calm and stable conditions during the night. The daily mean $\omega$ (at $675 \mathrm{~nm}$ ) ranged from 0.84 to 0.90 and the average $\omega$ was $0.87 \pm 0.02$.

Figure 10 shows the relationship between AOD and $\omega$ at $675 \mathrm{~nm}$ from 1.75-year measurements at the Bode site including the SusKat-ABC campaign period in the Kathmandu Valley. The AOD and $\omega$ (in parenthesis) values at $675 \mathrm{~nm}$ for each season were $0.14 \pm 0.07(0.88 \pm 0.05)$ in the monsoon, $0.19 \pm 0.13(0.87 \pm 0.05)$ in the post-monsoon, $0.21 \pm 0.1$ $(0.85 \pm 0.04)$ in the winter, and $0.43 \pm 0.2(0.84 \pm 0.06)$ in the pre-monsoon seasons. Contrary to Kim et al. (2005) who reported that $\omega$ increases as $\sigma_{\mathrm{s}}$ or $\sigma_{\mathrm{e}}$ increased under polluted conditions, the relationship between the AOD and $\omega$ across the four seasons in the Kathmandu Valley showed that $\omega$ decreased with increasing AOD. Here, we also compared the AOD and $\omega$ at the Kathmandu Valley with that from different environments at several sites in East and South Asia. The higher AOD values were observed in polluted regions, such as Beijing $(0.39 \pm 0.43)$ and Kanpur $(0.48 \pm 0.25)$; however, the AOD was lower in background regions such as Shirahama $(0.17 \pm 0.13)$, Maldives ( $0.22 \pm 0.11)$, Gosan $(0.25 \pm 0.19)$, and Anmyeon $(0.24 \pm 0.22)$. The AOD $(0.28 \pm 0.19)$ in the Kathmandu Valley was similar to that in background regions. However, $\omega(0.85 \pm 0.06)$ in the Kathmandu Valley was much lower than that in both the background (0.94 in Shirahama, Mal- 


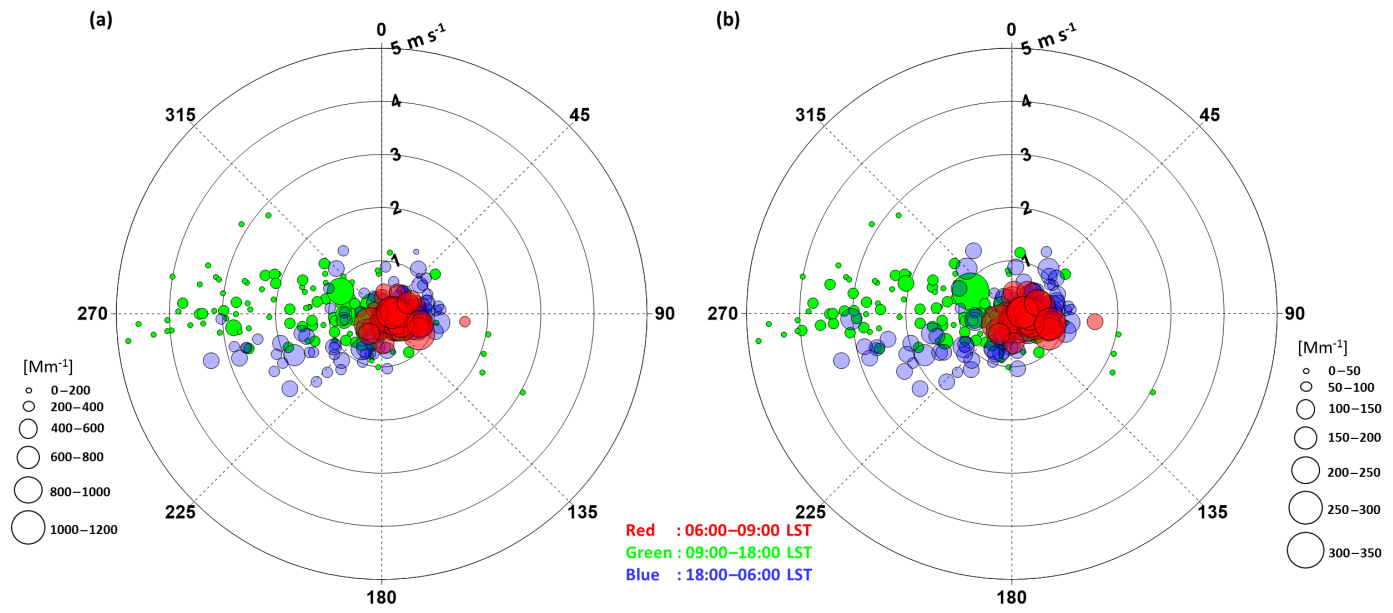

Figure 7. (a) Aerosol scattering coefficient and (b) aerosol absorption coefficient for three time periods of the day: morning (red dot; 06:00-09:00 LST), day (green dot; 09:00-18:00 LST), and night (blue dot; 18:00-06:00 LST) for different wind speeds (m s ${ }^{-1}$ ) and wind directions (degree).

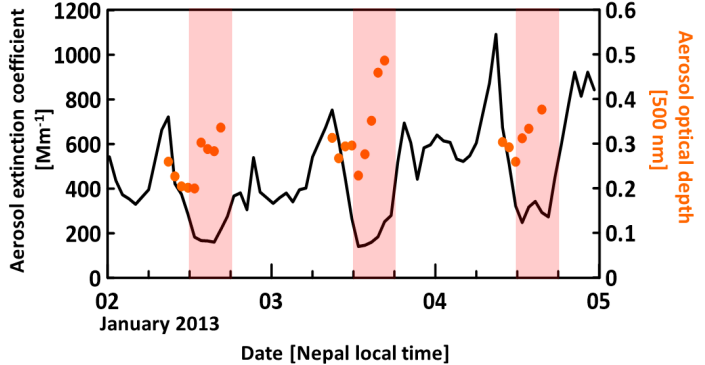

Figure 8. Variation in surface aerosol extinction coefficient $(550 \mathrm{~nm})$ and column aerosol optical depth $(500 \mathrm{~nm})$ at the Bode site from 2 to 4 January 2013.

dives, and Anmyeon; 0.95 in Gosan) and polluted regions (0.91 in Beijing; 0.90 in Kanpur). The low value of $\omega$ in the Kathmandu Valley suggests that the ratio of light-absorbing aerosols to total aerosols was much higher than in other regions, as we discussed in Sect. 3.

The high portion of light-absorbing aerosols resulted in atmospheric warming and cooling at the top of the atmosphere (TOA) and at the surface. The averaged $\triangle \mathrm{DRF}$ over the measurement period (21 December 2012-9 January 2013) was $-6.9 \pm 1.4 \mathrm{~W} \mathrm{~m}^{-2}$ at the TOA and $-20.8 \pm 4.6 \mathrm{~W} \mathrm{~m}^{-2}$ at the surface and thereby $13.9 \pm 3.6 \mathrm{~W} \mathrm{~m}^{-2}$ in the atmosphere (Fig. 9c). The high atmospheric forcing efficiency $\left(74.8 \pm 24.2 \mathrm{~W} \mathrm{~m}^{-2} \tau^{-1}\right)$ can be attributed to the high portion of light-absorbing aerosols in the Kathmandu Valley, as indicated by the high BC (or elemental carbon) to sulphate ratio (overall mean: $1.5 \pm 1.1$; see Sect. 3.2)

Figure 11 shows the comparison of the $\triangle \mathrm{DRF}$ and aerosol direct radiative forcing efficiency $(\triangle \mathrm{DRFe})$ at various environmental locations. There is a strong seasonal variation in

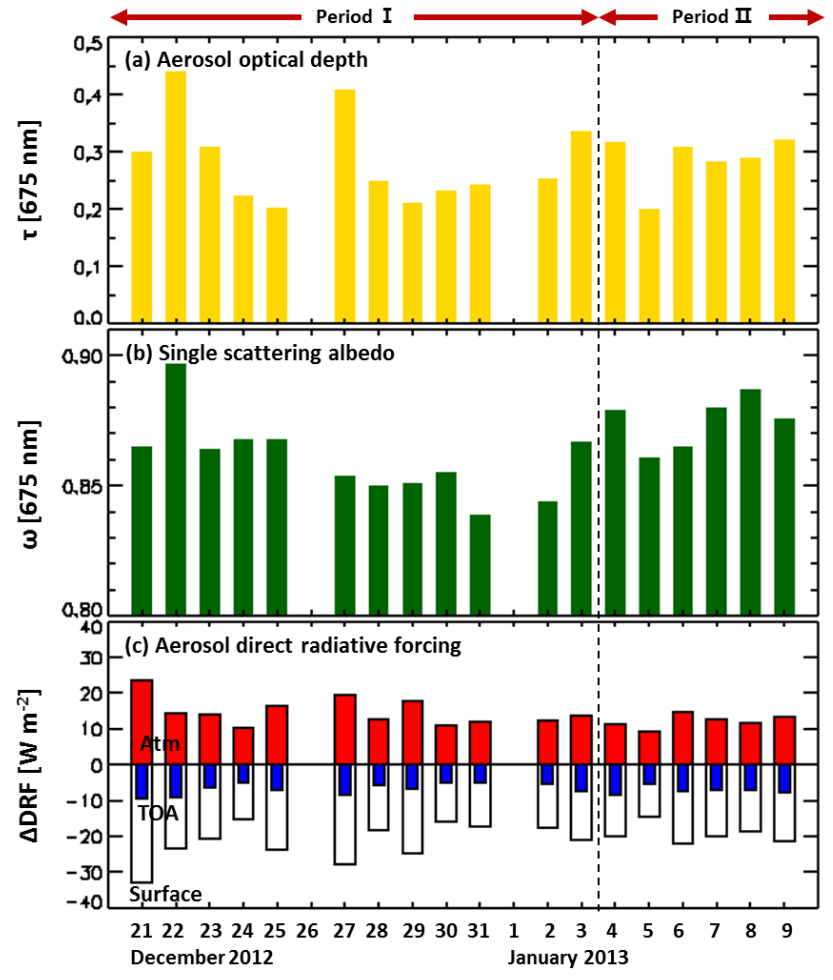

Figure 9. Daily variation in the (a) aerosol optical depth, (b) single scattering albedo, and (c) estimated aerosol radiative forcing at the surface, atmosphere (Atm), and top of atmosphere (TOA) in the Kathmandu Valley from 21 December 2012 to 9 January 2013.

$\triangle \mathrm{DRF}$ in the Kathmandu Valley, as we discussed for AOD. The $\triangle \mathrm{DRF}$ dramatically increased in the pre-monsoon season, with the highest values of $-5.0 \pm 5.7 \mathrm{~W} \mathrm{~m}^{-2}$ (TOA), $39.7 \pm 23.9 \mathrm{~W} \mathrm{~m}^{-2}$ (atmosphere), and $-44.7 \pm 22.1 \mathrm{~W} \mathrm{~m}^{-2}$ (surface). After the dry season, the summer monsoon de- 


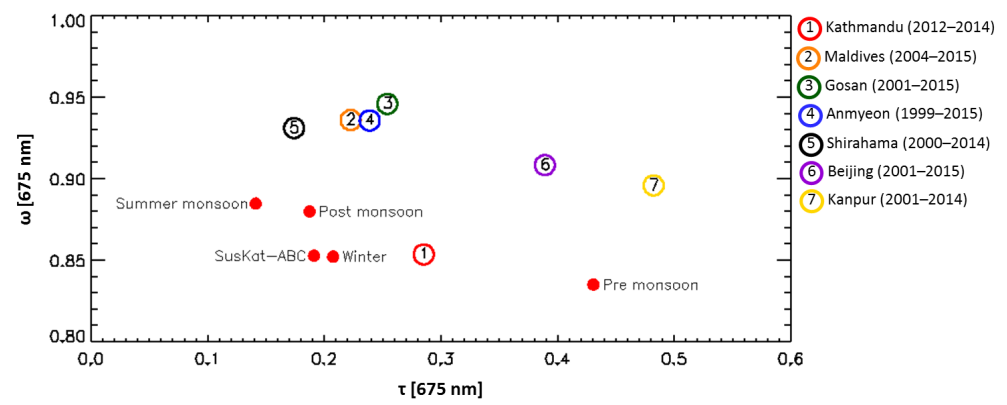

Figure 10. Relationship between the aerosol optical depth and single scattering albedo measured at several sites in East and South Asia (open circle with number, data period in parentheses) and in the Kathmandu Valley, segregated by season (closed circle).
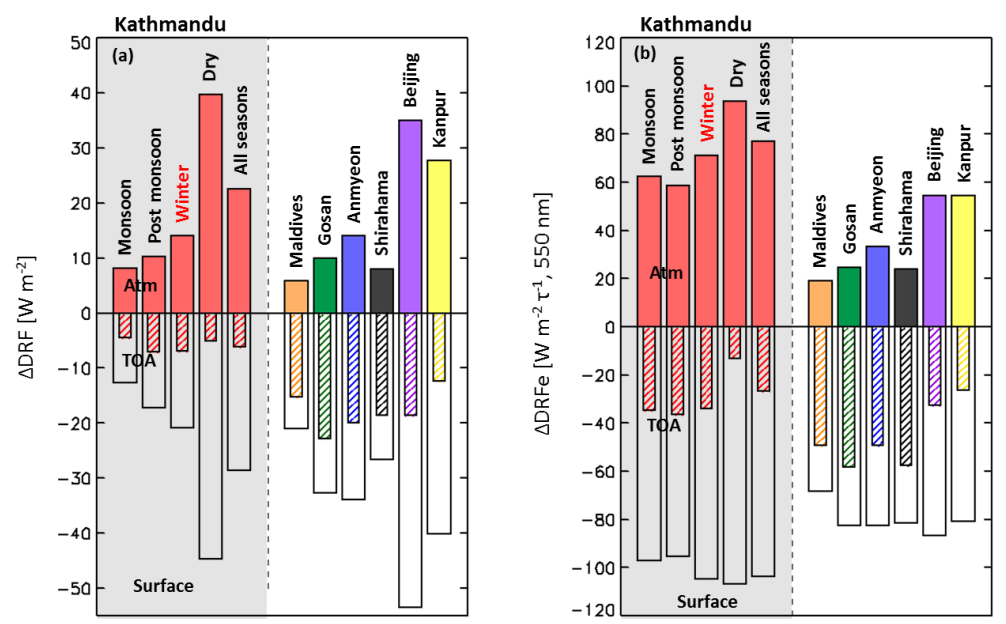

Figure 11. Comparison of the (a) aerosol radiative forcing and (b) aerosol radiative forcing efficiency in the Kathmandu Valley with that of other locations in Asia. The data period is the same as that given in Fig. 10.

pressions extended to Nepal from the southeastern Arabian or northern Bay of Bengal, producing heavy rain events (Ueno and Toyotsu, 2008). The substantial daily rainfall in the monsoon season scavenged the aerosols from the atmosphere, resulting in lower or similar values of $\triangle \mathrm{DRF}$ in the monsoon and post-monsoon seasons with those at other background sites (Maldives, Gosan, Anmyeon, and Shirahama). The average $\triangle \mathrm{DRF}$ in the Kathmandu Valley over the period of December 2012August 2014 was estimated to be $-6.1 \pm 4.3 \mathrm{~W} \mathrm{~m}^{-2}$ (TOA), $22.5 \pm 20 \mathrm{~W} \mathrm{~m}^{-2}$ (atmosphere), and $-28.6 \pm 19.1 \mathrm{~W} \mathrm{~m}^{-2}$ (surface). The $\triangle \mathrm{DRF}$ value of the atmosphere was roughly a factor of 2.5-3 higher than that at background stations: Maldives $\left(5.8 \pm 4.8 \mathrm{~W} \mathrm{~m}^{-2}\right)$, Shirahama $\left(8.0 \pm 6.0 \mathrm{~W} \mathrm{~m}^{-2}\right)$, Gosan $\left(10.2 \pm 8.5 \mathrm{~W} \mathrm{~m}^{-2}\right)$, and Anmyeon $\left(14 \pm 8.7 \mathrm{~W} \mathrm{~m}^{-2}\right)$. The $\triangle \mathrm{DRF}$ value of the atmosphere in the Kathmandu Valley was similar to that in polluted sites such as Beijing $\left(34.9 \pm 27.4 \mathrm{~W} \mathrm{~m}^{-2}\right)$ and Kanpur $\left(27.7 \pm 15.4 \mathrm{~W} \mathrm{~m}^{-2}\right)$. As we discussed in Fig. 10, the AOD and $\omega$ in Beijing and Kanpur were much higher than those in the Kathmandu Valley. Although the aerosol loadings over the Kathmandu Valley were lower than those in Beijing and Kanpur, this im- plies that atmospheric warming can be enhanced over the Kathmandu Valley due to the high portion of light-absorbing aerosols. This can be clearly seen in Fig. $11 \mathrm{~b}$. The $\triangle \mathrm{DRFe}$ of $-26.7 \pm 15 \mathrm{~W} \mathrm{~m}^{-2} \tau^{-1}$ (TOA), $76.9 \pm 32.7 \mathrm{~W} \mathrm{~m}^{-2} \tau^{-1}$ (atmosphere), and $-103.6 \pm 25.9 \mathrm{~W} \mathrm{~m}^{-2} \tau^{-1}$ (surface) in the Katmandu Valley was a factor of 1.5 higher than that at two urban sites mentioned above (Beijing and Kanpur) and 3 times higher than that at other background sites.

\section{Summary and conclusions}

In this study, we investigated the optical and chemical properties of aerosols and their direct radiative effects in the Kathmandu Valley during the SusKat-ABC campaign in the winter of 2012-2013. The principal findings of our analysis are summarized below:

- The 1.75-year AERONET Cimel sun/sky radiometer measurements at the Bode site in the Kathmandu Valley showed that the AOD in the winter and postmonsoon seasons was about 0.30. The AOD maxima were observed in the pre-monsoon season $(0.63 \pm 0.12$ 
at $675 \mathrm{~nm}$ ), whereas AOD minima occurred in the summer monsoon season $(0.19 \pm 0.1$ at $675 \mathrm{~nm})$. The seasonal variations are closely related to distinct seasonal monsoon circulations over South Asia including the Himalayan foothills.

- Both $\sigma_{\mathrm{s}}$ (average: $577 \pm 310 \mathrm{Mm}^{-1}$ at $550 \mathrm{~nm}$ ) and $\sigma_{\mathrm{a}}\left(145 \pm 82 \mathrm{Mm}^{-1}\right.$ at $\left.520 \mathrm{~nm}\right)$ values increased distinctly after 4 January 2013 compared with the period from 21 December 2012 to 3 January $2013\left(\sigma_{\mathrm{s}}\right.$ : $\left.313 \pm 135 \mathrm{Mm}^{-1}, \sigma_{\mathrm{a}}: 98 \pm 146 \mathrm{Mm}^{-1}\right)$. This noticeable increase can be attributed to emissions from brick kilns (operations started 4 January 2013). The $\sigma_{\mathrm{s}}$ value in the Kathmandu Valley was a factor of 0.5-0.6 lower than those observed in polluted urban cities (Hisar and Allahabad) in India, while it was similar to those in Beijing in China. The $\sigma_{\mathrm{a}}$ value in the Kathmandu Valley was roughly a factor of 12 higher than that at other background sites and more than 2 times higher than those at severely polluted urban sites in India.

- The aerosol mass scattering efficiency of $2.6 \mathrm{~m}^{2} \mathrm{~g}^{-1}$ in the Kathmandu Valley is similar to those reported in other urban areas. However, the aerosol absorption efficiency of $11 \mathrm{~m}^{2} \mathrm{~g}^{-1}$ is $47 \%$ higher than that of pure soot particles $\left(7.5 \pm 1.2 \mathrm{~m}^{2} \mathrm{~g}^{-1}\right.$; Bond and Bergstrom, 2006). This is thought to be due to the fact that most of the carbonaceous aerosols in Kathmandu Valley are fresh aerosols and are mostly externally mixed with other aerosols under dry conditions because of the short travel time and distance from their sources to the observation site at Bode.

- The aerosol optical properties from in situ surface measurements showed distinct diurnal variations, coupled with the development of local circulations and the boundary layer height in the Kathmandu basin. The $\sigma_{\mathrm{s}}$, $\sigma_{\mathrm{a}}$, and EBC mass concentration values reached up to $757 \mathrm{Mm}^{-1}, 224 \mathrm{Mm}^{-1}$, and $29 \mu \mathrm{g} \mathrm{m}^{-3}$ at 08:00 LST, respectively, mainly due to high emissions from increased motor vehicles in the traffic rush hour, cooking activities in the morning (06:00-09:00 LST), and pre-existing aerosols under calm and stable conditions. Because of the development of valley winds and the boundary layer during the daytime (09:00-18:00 LST), these values reduced to one-quarter of the morning average. After sunset, the $\sigma_{\mathrm{s}}, \sigma_{\mathrm{a}}$, and EBC mass concentration values were back at $410 \pm 163 \mathrm{Mm}^{-1}, 130 \pm 47 \mathrm{Mm}^{-1}$, and $17 \pm 6 \mu \mathrm{g} \mathrm{m}^{-3}$, respectively, and remained constant throughout the night.
- The $\triangle \mathrm{DRF}$ in Kathmandu was estimated to be $-6.1 \pm 4.3 \mathrm{~W} \mathrm{~m}^{-2}$ (TOA), $22.5 \pm 20 \mathrm{~W} \mathrm{~m}^{-2}$ (atmosphere), and $-28.6 \pm 19.1 \mathrm{~W} \mathrm{~m}^{-2}$ (surface). The high atmospheric forcing (i.e., atmospheric warming) and forcing efficiency $\left(76.9 \pm 32.7 \mathrm{~W} \mathrm{~m}^{-2} \tau^{-1}\right)$ can be attributed to the high proportion of light-absorbing aerosols in the aerosol composition, as indicated by the high $\mathrm{BC}(\mathrm{EC})$ to sulphate ratio $(1.5 \pm 1.1)$.

The mitigation of high aerosol concentrations in the Kathmandu Valley is of particular importance, especially that of particulate carbon, to improve the health, visibility, and climate effects. The continuous comprehensive measurements of aerosol chemical compositions and associated optical and radiative properties and detailed air quality modeling in this region are necessary to develop the most effective mitigation strategies and control measures. This study only covers a short period of the dry winter season, but it provides unprecedented insights into aerosol optical properties and their radiative forcings in the Kathmandu Valley. Further measurements, particularly at the surface level, and investigations during both winter and pre-monsoon periods (November to June) are required to understand the seasonal characteristics at both the surface and columnar levels.

Data availability. The in situ observational data of surface aerosol properties and meteorological variables collected for this study during the SusKat-ABC campaign in Nepal can be obtained by directly contacting the corresponding author of this paper at sangwookim@snu.ac.kr. These data will also be made public through a website maintained by the Institute for Advanced Sustainability Studies (IASS), Potsdam, Germany. The column-integrated aerosol data are available at https://aeronet.gsfc.nasa.gov/. 


\section{Appendix A: Nomenclature}

\begin{tabular}{ll}
\hline Symbol & Definition \\
$\sigma_{\mathrm{s}}$ & aerosol scattering coefficient \\
$\sigma_{\mathrm{a}}$ & aerosol absorption coefficient \\
$\sigma_{\mathrm{e}}$ & aerosol extinction coefficient \\
$\mathrm{SÅE}$ & scattering Ångström exponent \\
$\mathrm{EBC}$ & equivalent black carbon \\
$\mathrm{EC}$ & elemental carbon \\
$\mathrm{OC}$ & organic carbon \\
$\mathrm{TC}$ & total carbon (i.e., sum of organic and elemental carbon) \\
$Q_{\mathrm{s}}$ & aerosol mass scattering efficiency \\
$Q_{\mathrm{a}}$ & aerosol mass absorption efficiency \\
AOD, $\tau$ & aerosol optical depth \\
$\omega$ & single scattering albedo \\
$g$ & asymmetric parameter \\
$\AA$ & Angström exponent \\
$\lambda$ & wavelength \\
$\Delta \mathrm{DRF}$ & aerosol direct radiative forcing \\
$\Delta \mathrm{DRFe}$ & aerosol direct radiative forcing efficiency \\
$\mathrm{MLH}$ & mixing layer height \\
LST & local standard time \\
\hline
\end{tabular}


Competing interests. The authors declare that they have no conflict of interest.

Special issue statement. This article is part of the special issue "Atmospheric pollution in the Himalayan foothills: The SusKat-ABC international air pollution measurement campaign". It is not associated with a conference.

Acknowledgements. This study was supported by the Korea Meteorological Administration Research and Development Program under the grant KMIPA "2015-2011" and the Korean Ministry of Environment ("Climate Change Correspondence"). The IASS coauthors acknowledge their funding agencies, the German Federal Ministry for Education and Research (BMBF) and the Brandenburg Ministry for Science, Research, and Culture (MWFK).

Edited by: Sachin S. Gunthe

Reviewed by: two anonymous referees

\section{References}

Anderson, T. L. and Ogren, J. A.: Determining aerosol radiative properties using the TSI 3563 integrating Nephelometer, Aerosol Sci. Tech., 29, 57-69, https://doi.org/10.1080/02786829808965551, 1998.

Bergin, M. H., Cass, G. R., Xu, J., Fang, C., Zeng, L. M., Yu, T., Salmon, L. G., Kiang, C. S., Tang, X. Y., Zhang, Y. H., and Chameides, W. L.: Aerosol radiative, physical, and chemical properties in Beijing during June 1999, J. Geophys. Res., 106, 17969-17980, https://doi.org/10.1029/2001JD900073, 2001.

Bond, T. C. and Bergstrom, R. W.: Light absorption by carbonaceous particles: An investigative review, Aerosol Sci. Tech., 40, 27-67, https://doi.org/10.1080/02786820500421521, 2006.

Briegleb, B.: Delta-Eddington approximation for solar radiation in the NCAR community climate model, J. Geophys. Res., 97, 7603-7612, https://doi.org/10.1029/92JD00291, 1992.

Carrico, C. M., Bergin, M. H., Shrestha, A. B., Dibb, J. E., Gomes, L., and Harris, J. M.: The importance of carbon and mineral dust to seasonal aerosol properties in the Nepal Himalays, Atmos. Environ., 37, 2811-2824, https://doi.org/10.1016/S13522310(03)00197-3, 2003

CBS - Central Bureau of Statistics: Statistical Year Book of Nepal, Nepal Government, Kathmandu, Nepal, 2006.

Chen, P., Kang, S., Li, C., Rupakheti, M., Yan, F., Li, Q., Ji, Z., Zhang, Q., Luo, W., and Sillanpää, M.: Characteristics and sources of polycyclic aromatic hydrocarbons in atmospheric aerosols in the Kathmandu Valley, Nepal, Sci. Total Environ., 538, 86-92, https://doi.org/10.1016/j.scitotenv.2015.08.006, 2015.

Hansen, A. D. A., Rosen, H., and Novakov, T.: The aethalometer - An instrument for the real-time measurement of optical absorption by aerosol particles, Sci. Total Environ., 36, 191-196, https://doi.org/10.1016/0048-9697(84)90265-1, 1984.

Jacobson, M. Z. A.: Investigating cloud absorption effects: Global absorption properties of black carbon, tar balls, and soil dust in clouds and aerosols, J. Geophys. Res., 117, D06205, https://doi.org/10.1029/2011JD017218, 2012.

Kim, B. M., Park, J.-S., Kim, S.-W., Kim, H., Jeon, H., Cho, C., Kim, J.-H., Hong, S., Rupakheti, M., Panday, A. K., Park, R. J., Hong, J., and Yoon, S.-C.: Source apportionment of $\mathrm{PM}_{10}$ mass and particulate carbon in the Kathmandu Valley, Nepal, Atmos. Environ., 123, 190-199, https://doi.org/10.1016/j.atmosenv.2015.10.082, 2015.

Kim, S.-W., Choi, I.-J., and Yoon, S.-C.: A multi-year analysis of clear-sky aerosol optical properties and direct radiative forcing at Gosan, Korea (2001-2008), Atmos. Res., 95, 279-287, https://doi.org/10.1016/j.atmosenv.2004.09.056, 2005.

Kim, S.-W., Yoon, S.-C., Jefferson, A., Ogren, J. A., Dutton, E. G., Won, J.-G., Ghim, Y. S., Lee, B.-I., and Han, J.-S.: Aerosol optical, chemical and physical properties at Gosan, Korea during Asian dust and pollution episodes in 2001, Atmos. Environ., 39, 39-50, https://doi.org/10.1016/j.atmosres.2009.10.008, 2010.

Kiros, F., Shakya, K. M., Rupakheti, M., Regmi, R. P., Maharjan, R., Byanju, R. M., Naja, M., Mahata, K., Kathayat, B., and Peltier, R. E.: Variability of anthropogenic gases: Nitrogen Oxides, Sulfur Dioxide, Ozone and Ammonia in Kathmandu Valley, Nepal, Aerosol Air Qual. Res., 16, 3088-3101, https://doi.org/10.4209/aaqr.2015.07.0445, 2016.

Liousse, C., Cachier, H., and Jennings, S. G.: Optical and thermal measurements of black carbon aerosol content in different environments: Variation of the specific attenuation cross-section, sigma $(\sigma)$, Atmos. Environ. A, 27, 1203-1211, https://doi.org/10.1016/0960-1686(93)90246-U, 1993.

Mues, A., Rupakheti, M., Münkel, C., Lauer, A., Bozem, H., Hoor, P., Butler, T., and Lawrence, M. G.: Investigation of the mixing layer height derived from ceilometer measurements in the Kathmandu Valley and implications for local air quality, Atmos. Chem. Phys., 17, 8157-8176, https://doi.org/10.5194/acp17-8157-2017, 2017.

Panday, A. K., and Prinn, R. G.: Diurnal cycle of air pollution in the Kathmandu Valley, Nepal: Observations, J. Geophys. Res., 114, D09305, https://doi.org/10.1029/2008JD009777, 2009.

Pariyar, S. K., Das, T., and Ferdous, T.: Environment and health impact for brick kilns in Kathmandu Valley, Int. J. Sci. Tech. Res., 2, 184-187, 2013.

Putero, D., Cristofanelli, P., Marinoni, A., Adhikary, B., Duchi, R., Shrestha, S. D., Verza, G. P., Landi, T. C., Calzolari, F., Busetto, M., Agrillo, G., Biancofiore, F., Carlo, P. D., Panday, A. K., Rupakheti, M., and Bonasoni, P.: Seasonal variation of ozone and black carbon observed at Paknajol, an urban site in the Kathmandu Valley, Nepal, Atmos. Chem. Phys., 15, 13957-13971, https://doi.org/10.5194/acp-15-13957-2015, 2015.

Ram, K., Sarin, M. M., Sudheer, A. K., and Rengarajan, R.: Carbonaceous and secondary inorganic aerosols during wintertime fog and haze over urban sites in the Indo-Gangetic Plain, Aerosol Air Qual. Res., 12, 359-370, https://doi.org/10.4209/aaqr.2011.07.0105, 2012.

Ramana, M. V., Ramanathan, V., Podgorny, I. A., Pradhan, B. B., and Shrestha, B.: The direct observations of large aerosol radiative forcing in the Himalayan region, Geophys. Res. Lett., 31, L05111, https://doi.org/10.1029/2003GL018824, 2004.

Ramana, M. V., Ramanathan, V., Feng, Y., Yoon, S.-C., Kim, S.-W., Carmichael, G. R., and Schauer, J. J.: Warming influenced by the 
ratio black carbon to sulphate and the black-carbon source, Nat. Geosci., 3, 542-545, https://doi.org/10.1038/NGEO918, 2010.

Raut, A. K.: Brick Kilns in Kathmandu Valley: Current status, environmental impacts and future options, Himal. J. Sci., 1, 59-61, https://doi.org/10.3126/hjs.v1i1.189, 2003.

Regmi, R. P., Kitada, T., and Kurata, G.: Numerical simulation of late wintertime local flows in Kathmandu Valley, Nepal: Implication of air pollution transport, J. Appl. Meteorol., 42, 389-403, https://doi.org/10.1175/15200450(2003)042<0389:NSOLWL>2.0.CO;2, 2003.

Rupakheti, M., Panday, A. K., Lawrence, M. G., Kim, S. W., Sinha, V., Kang, S. C., Naja, M., Park, J. S., Hoor, P., Holben, B., Sharma, R. K., Mues, A., Mahata, K. S., Bhardwaj, P., Sarkar, C., Rupakheti, D., Regmi, R. P., and Gustafsson, Ö.: Air pollution in the Himalayan foothills: overview of the SusKat-ABC 50 international air pollution measurement campaign in Nepal, in preparation, 2017.

Sapkota, B. and Dhaubhadel, R.: Atmospheric turbidity over Kathmandu Valley, Atmos. Environ., 36, 1249-1257, https://doi.org/10.1016/S1352-2310(01)00582-9, 2002.

Sarkar, C., Shinha, V., Kumar, V., Rupakheti, M., Panday, A., Mahata, K. S., Rupakheti, D., Kathayat, B., and Lawrence, M. G.: Overview of VOC emissions and chemistry from PTR-TOFMS measurements during the SusKat-ABC campaign: high acetaldehyde, isoprene and isocyanic acid in wintertime air of the Kathmandu Valley, Atmos. Chem. Phys., 16, 3979-4003, https://doi.org/10.5194/acp-16-3979-2016, 2016.

Sarkar, C., Sinha, V., Sinha, B., Panday, A. K., Rupakheti, M., and Lawrence, M. G.: Source apportionment of NMVOCs in the Kathmandu Valley during the SusKat-ABC international field campaign using positive matrix factorization, Atmos. Chem. Phys., 17, 8129-8156, https://doi.org/10.5194/acp17-8129-2017, 2017.

Schmid, O., Artaxo, P., Arnott, W. P., Chand, D., Gatti, L. V., Frank, G. P., Hoffer, A., Schnaiter, M., and Andreae, M. O.: Spectral light absorption by ambient aerosols influenced by biomass burning in the Amazon Basin. I: Comparison and field calibration of absorption measurement techniques, Atmos. Chem. Phys., 6, 3443-3462, https://doi.org/10.5194/acp-6-3443-2006, 2006.

Schwarz, J. P., Gao, R. S., Spackman, J. R., Watts, L. A., Thomson, D. S., Fahey, D. W., Ryerson, T. B., Peischl, J., Holloway, J. S., Trainer, M., Frost, G. J., Baynard, T., Lack, D. A., de Gouw, J. A., Warneke, C., and Del Negro L. A.: Measurement of the mixing state, mass, and optical size of individual black carbon particles in urban and biomass burning emissions, Geophys. Res. Lett., 35, L13810, https://doi.org/10.1029/2008GL033968, 2008.
Sharma, R. K., Bhattarai, B. K., Sapkota, B. K., Gewali, M. B., and Kjeldstad, B.: Black carbon aerosols variation in Kathmnadu Valley, Nepal, Atmos. Environ., 63, 282-288, https://doi.org/10.1016/j.atmosenv.2012.09.023, 2012.

Shrestha, I. L. and Shrestha, S. L.: Indoor air pollution from biomass fuels and respiratory health of the exposed population in Nepalese households, Int. J. Occup. Environ. Health, 2, 150 160, https://doi.org/10.1179/oeh.2005.11.2.150, 2005.

Slingo, A.: A GCM parameterization for the shortwave radiative properties of water clouds, J. Atmos. Sci., 46, 1419-1427, https://doi.org/10.1175/1520 0469(1989)046<1419:AGPFTS>2.0.CO;2, 1989.

Stone, E. A., Schauer, J. J., Pradhan, B. B., Dangol, P. M., Habib, G., Venkataraman, C., and Ramanathan, V.: Characterization of emissions from South Asian biofuels and application to source apportionment of carbonaceous aerosol in the Himalayas, J. Geophys. Res., 115, D06301, https://doi.org/10.1029/2009JD011881, 2010.

Sun, Y., Zhuang, G., Tang, A., Wang, Y., and An, Z.: Chemical characteristics of $\mathrm{PM}_{2.5}$ and $\mathrm{PM}_{10}$ in haze-fog episodes in Beijing, Environ. Sci. Technol., 40, 3148-3155, https://doi.org/10.1021/es051533g, 2006.

Ueno, K. and Toyotsu, K.: Stepwise onset of monsoon weather observed in the Nepal Himalaya, Mon. Weather Rev., 136, 2507 2522, https://doi.org/10.1175/2007MWR2298.1, 2008.

Venzac, H., Sellegri, K., Laj, P., Villani, P., Bonasoni, P., Marinoni, A., Cristofanelli, P., Calzolari, F., Fuzzi, S., Decesari, S., Facchini, M.-C., Vuillermoz, E., and Verza, G. P.: High frequency new particle formation in the Himalayas, P. Natl. Acad. Sci. USA, 105, 15666-15671, https://doi.org/10.1073/pnas.0801355105, 2008.

Won, J.-G., Yoon, S.-C., Kim, S.-W., Jefferson, A., Dutton, E. G., and Holben, B.: Estimation of direct radiative forcing of Asian dust aerosols with sun/sky radiometer and lidar measurement at Gosan. Korea, J. Meteorol. Soc. Jpn., 82, 115-130, https://doi.org/10.2151/jmsj.82.115, 2004.

Xu, J., Bergin, M. H., Yu, X., Liu, G., Zhao, J., Carrico, C. M., and Baumann, K.: Measurement of aerosol chemical, physica and radiative properties in the Yangtze delta region of China, Atmos. Environ., 36, 161-173, https://doi.org/10.1016/S13522310(01)00455-1, 2002.

Xu, J., Bergin, M. H., Greenwald, R., Schauer, J. J., Shafer, M. M., Jaffrezo, J. L., and Aymoz, G.: Aerosol chemical, physical, and radiative characteristics near a desert source region of northwest China during ACE-Asia, J. Geophys. Res., 109, D19S03, https://doi.org/10.1029/2003JD004239, 2004. 